\title{
Hemiuterus with functional non- communicating horn in a young female
}

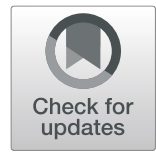

\author{
M. Venkatesh ${ }^{1}$ and Sandeep Singh Awal ${ }^{2^{*}}$ (D)
}

\begin{abstract}
Background: Mullerian duct anomalies are a broad spectrum of congenital anomalies of the female genital tract presenting with variable symptoms like infertility, amenorrhoea, dysmenorrhea, pelvic endometriosis, and poor obstetric outcomes. Unicornuate uterus or hemiuterus occurs as a result of abnormal formation or failure of formation of the contralateral part.

Case presentation: We present a rare case report of hemiuterus with functional non-communicating horn along with hematometra in a 15-year-old female who presented with severe dysmenorrhoea since her menarche. Pelvic Ultrasonography demonstrated inconclusive findings of a heterogenous lesion in the right pelvic cavity adjacent to the uterus. Further, pelvic MRI revealed a hemiuterus on the left side with a normal endometrial cavity and a welldefined functional non-communicating horn on right side. The diagnosis of European Society of Human Reproduction (ESHRE) Classification U4a uterine anomaly (left hemiuterus with functional non-communicating horn on right side) was established.

Conclusions: ESHRE Class U4a comprises of hemiuterus with a functional rudimentary horn. This is considered clinically significant as it may lead to further complications, such as hematometra or ectopic pregnancy in the rudimentary horn. Hence, the correct identification of this entity is essential as laparoscopic removal is the current recommended management.
\end{abstract}

Keywords: Mullerian duct anomalies, Hemiuterus, Rudimentary horn, Dysmenorrhea, Case report

\section{Background}

Mullerian duct anomalies (MDA) belong to a broad spectrum of congenital anomalies of uterus and vagina which occur due to developmental defects in the Mullerian ducts [1]. These anomalies can present with various symptoms like infertility, amenorrhoea, dysmenorrhoea, pelvic endometriosis, and associated obstetric complications [2]. Hysterosalpingography (HSG) is initially used to diagnose structural anomalies of the female genital tract [3]. However, HSG lacks in the capability of characterizing the external morphology of the uterus and classifying the subtype of the anomaly. With the advent of newer modalities, HSG has been supplanted by pelvic ultrasonography

\footnotetext{
* Correspondence: jonty3awal@gmail.com

${ }^{2}$ Department of Radiology, Brahmananda Narayana Multispecialty Hospital, Jamshedpur, India

Full list of author information is available at the end of the article
}

(USG) and pelvic magnetic resonance imaging (MRI). Pelvic MRI is considered superior to pelvic ultrasonography for the diagnosis and classification of Mullerian duct anomalies as it provides excellent soft tissue depiction owing to its multiplanar capabilities $[4,5]$.

We present a rare case report of left hemiuterus with functional non-communicating horn on right side along with hematometra.

\section{Case presentation}

A 15-year-old female presented with severe dysmenorrhea since her menarche. She attained menarche at the age of 13 years with regular menstrual cycles of 22-25 days in duration. The pain was mildly alleviated by analgesics. On general examination, her blood pressure was $120 / 80 \mathrm{mmHg}$ with heart rate of 78 beats/min. Her secondary sexual characters were well developed.

\section{Springer Open}

(c) The Author(s). 2021 Open Access This article is licensed under a Creative Commons Attribution 4.0 International License, which permits use, sharing, adaptation, distribution and reproduction in any medium or format, as long as you give appropriate credit to the original author(s) and the source, provide a link to the Creative Commons licence, and indicate if changes were made. The images or other third party material in this article are included in the article's Creative Commons licence, unless indicated otherwise in a credit line to the material. If material is not included in the article's Creative Commons licence and your intended use is not permitted by statutory regulation or exceeds the permitted use, you will need to obtain permission directly from the copyright holder. To view a copy of this licence, visit http://creativecommons.org/licenses/by/4.0/. 


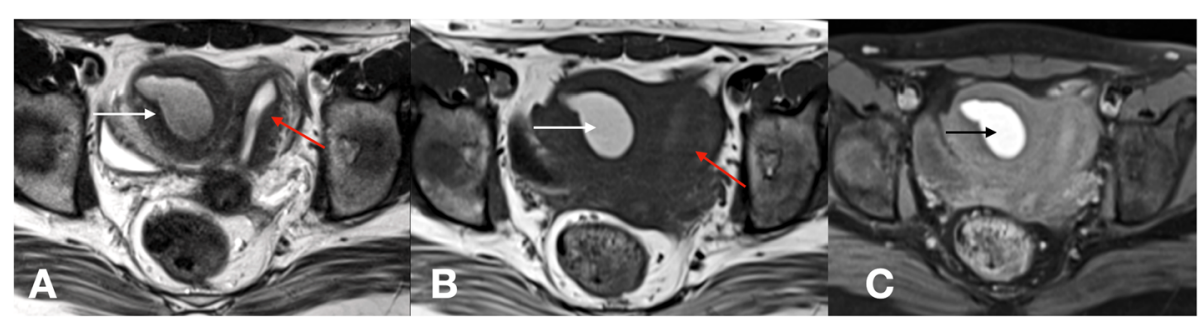

Fig. 1 a-c Axial T2 (a) showing cavity with hematometra (white arrow) towards right side and is in continuity with the left hemiuterus (red arrow). Axial T1 (b) and T1 fat surpassed images (c) showing hyperintense fluid in the horn on right side (white arrow and black arrow) suggestive of hematometra

Ultrasound of the pelvis was done which revealed a heterogenous, hypoechoic lesion adjacent to the uterus on the right side. The above findings on ultrasound were inconclusive.

Pelvis MRI with axial T1, T2, T1 FS (3 mm thickness), sagittal T2 (4 mm thickness), axial gradient echo (4 mm thickness) sequences were performed. Pelvic MRI (Fig. 1a-c) revealed a hemiuterus measuring $5.8 \times$ $2.8 \times 3 \mathrm{~cm}$ in size with a normal endometrial cavity. A well-defined structure measuring $4.5 \times 4.2 \mathrm{~cm}$ was noted in contact with the hemiuterus on right side and showed endometrial cavity within. The endometrial cavity demonstrated loculated T1 hyperintense content within, suggestive of hematometra. No obvious communication was noted with the hemiuterus. Single cervical cavity was seen (Fig. 2a). No vaginal septum was seen (Fig. 2b). Bilateral ovaries and adnexa showed normal morphology. The diagnosis of ESHRE Classification U4a C0 V0 uterine anomaly (left hemiuterus with functional non-communicating horn on right side) was established (Fig. 2c). No associated renal anomalies were present.

\section{Discussion}

The prevalence of Mullerian duct anomalies (MDA) ranges from 1 to 5\% [6-9]. However, in women presenting with recurrent pregnancy loss, the prevalence is significantly higher (up to 15\%) [9]. Hence, the correct identification and classification of Mullerian duct anomalies is clinically significant. The importance of a universalized and comprehensive classification for congenital anomalies of the female genital tract cannot be understated [10].

The European Society of Human Reproduction (ESHR E)/European Society of Gynecological Endoscopy (ESGE) consensus [11] classifies congenital anomalies of the female genital tract categories on the basis of anatomical variations as follows:

Class U0 incorporates normal uterus. Class U1 comprises dysmorphic uterus. Separate uterus is considered as Class U2. All fusion defects are classified under U3 or Bi-corporeal uterus. Unilaterally formed uterus or hemiuterus is included under Class U4. Aplastic uterus is considered as Class U5. A separate class, U6 is reserved for still classified cases [11].

Class U4 is further subdivided into classes U4a and U4b depending on the morphological characteristics of the contralateral poorly formed part. If the rudimentary horn/cavity is functional, it is classified as Class U4a irrespective of it being communicating or noncommunicating. Non-functional rudimentary horn/cavity is categorized as Class U4b [11].

ESHRE Class U4a (hemiuterus with a functional rudimentary horn/cavity) is associated with obstetric and gynecological complications such as hematometra and ectopic pregnancy [11-14]. Due to this reason, laparoscopic removal of Class U4a rudimentary horn is the current recommended line of management [15].

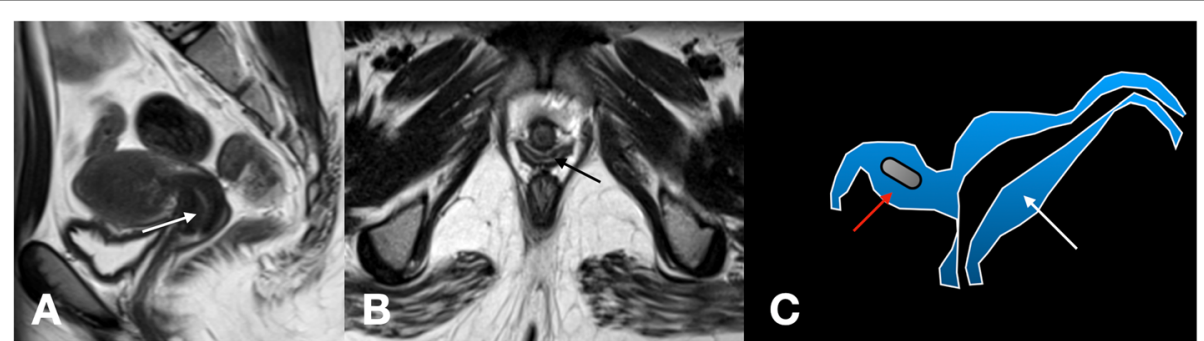

Fig. 2 a-c Sagittal (a) and axial (b) T2 images showing normal cervix (white arrow) and normal vagina (black arrow). Illustration of our case (c) showing hemiuterus (white arrow) and functional non-communicating horn with hematometra (red arrow) 


\section{Conclusions}

Mullerian duct anomalies incorporate wide spectrum of congenital anomalies of the female genital tract. Imaging plays crucial role in the diagnosis and classification of the Mullerian duct anomalies. Class U4a MDA represents a hemiuterus with a functional rudimentary horn/ cavity and has been associated with complications such as haematometra and ectopic pregnancy. Hence, the correct identification of this rare entity is essential to improve the morbidity and prevent further obstetric and/or gynecological complications.

\section{Abbreviations}

MDA: Mullerian duct anomalies; ESHRE: European Society of Human Reproduction; ESGE: European Society of Gynaecological Endoscopy; MRI: Magnetic resonance imaging; HSG: Hysterosalpingography; USG: Ultrasonography; FS: Fat saturated

\section{Acknowledgements}

Not applicable.

\section{Authors' contributions}

VM: conceived of the study, analyzed and interpreted the radiological study, participated in manuscript design, designed illustrations, and helped in drafting the manuscript. SSA: drafted the manuscript, participated in manuscript design and coordination. The authors read and approved the final manuscript.

\section{Funding}

Not applicable.

\section{Availability of data and materials}

The data and materials supporting the findings of this study are available on request from the corresponding author.

\section{Declarations}

\section{Ethics approval and consent to participate}

This study was approved from ethical committee of the institution. Written informed consent was obtained from the patient for publication of this case report and accompanying images.

\section{Consent for publication}

All authors read and approved the final manuscript. Patient included in this research gave written informed consent to publish the data and materials contained within this study.

\section{Competing interests}

The authors declare that they have no competing interests.

\section{Author details}

${ }^{1}$ Department of Radiology, Narayana Medical College \& Hospital, Nellore, India. ${ }^{2}$ Department of Radiology, Brahmananda Narayana Multispecialty Hospital, Jamshedpur, India.

Received: 12 February 2021 Accepted: 3 May 2021

Published online: 17 May 2021

\section{References}

1. Chandler TM, Machan LS, Cooperberg PL, Harris AC, Chang SD (2009) Mullerian duct anomalies: from diagnosis to intervention. Br J Radiol 82(984):1034-1042. https://doi.org/10.1259/bjr/99354802

2. Kachhawa G, Kriplani A (2017) Management of reproductive tract anomalies. J Obstet Gynaecol India 67(3):162-167

3. Simpson WL Jr, Beitia LG, Mester J (2006) Hysterosalpingography: a reemerging study. RadioGraphics. 26(2):419-431. https://doi.org/10.1148/rg.2 62055109
4. Maciel C, Bharwani N, Kubik-Huch RA, Manganaro L, Otero-Garcia M, Nougaret S, Alt CD, Cunha TM, Forstner R (2020) MRI of female genital tract congenital anomalies: European Society of Urogenital Radiology (ESUR) guidelines. Eur Radiol 30(8):4272-4283. https://doi.org/10.1007/ s00330-020-06750-8

5. Saleem SN (2003) MR imaging diagnosis of uterovaginal anomalies: current state of the art. RadioGraphics 23(5):e13. https://doi.org/10.1148/rg.e13

6. Behr SC, Courtier JL, Qayyum A (2012) Imaging of Müllerian duct anomalies. RadioGraphics 32:E233-E250 October Special Issue 2012

7. Chan YY, Jayaprakasan K, Zamora J, Thornton JG, Raine-Fenning N, Coomarasamy A (2011) The prevalence of congenital uterine anomalies in unselected and high-risk populations: a systematic review. Hum Reprod Update 17(6):761

8. Grimbizis GF, Camus M, Tarlatzis BC, Bontis JN, Devroey P (2001) Clinical implications of uterine malformations and hysteroscopic treatment results. Hum Reprod Update 7(2):161

9. Acién P (1997) Incidence of Müllerian defects in fertile and infertile women. Hum Reprod 12(7):1372

10. Di Spiezio Sardo A, Campo R, Gordts S, Spinelli M, Cosimato C, Tanos V, Brucker S, Li TC, Gergolet M, De Angelis C, Gianaroli L, Grimbizis G (2015) The comprehensiveness of the ESHRE/ESGE classification of female genital tract congenital anomalies: a systematic review of cases not classified by the AFS system. Hum Reprod 30(5):1046

11. Grimbizis GF, Gordts S, Di Spiezio Sardo A, Brucker S, De Angelis C, Gergolet M, Li T-C, Tanos V, Brölmann H, Gianaroli L, Campo R (2013) The ESHRE/ ESGE consensus on the classification of female genital tract congenital anomalies. Hum Reprod 28(8):2032

12. Kumari S, Gupta P, Jyoti PS (2019) A rare case of pregnancy in the rudimentary horn of unicornuate uterus (on table diagnosis): a case report. Int J Reprod Contracept Obstet Gynecol 8(3):1190

13. Johansen JK (1969) Pregnancy in a rudimentary horn. Two case reports. Obstet Gynecol 34(6):805-808

14. Kamal S, Roy P (2017) A study of complications in case of unicornuate uterus with rudimentary horn. Int J Reprod Contracept Obstet Gynecol 6(6):2607

15. Fedele L, Fedele BS, Fedele ZG, Fedele BN, Fedele BV, Fedele (2005) Laparoscopic removal of the cavitated noncommunicating rudimentary uterine horn: surgical aspects in 10 cases. Fertil Steril 83(2):432-436

\section{Publisher's Note}

Springer Nature remains neutral with regard to jurisdictional claims in published maps and institutional affiliations.

\section{Submit your manuscript to a SpringerOpen ${ }^{\circ}$ journal and benefit from:}

- Convenient online submission

- Rigorous peer review

- Open access: articles freely available online

High visibility within the field

- Retaining the copyright to your article

Submit your next manuscript at $>$ springeropen.com 